\title{
Corticosteroids and corticotrophin in the treatment of Crohn's disease
}

\author{
J. HOWEL JONES AND J. E. LENNARD-JONES ${ }^{1}$ \\ From the Department of Gastroenterology, Central Middlesex Hospital, London
}

EDITORIAL SYNOPSIS This paper presents results in the treatment of 105 patients suffering from Crohn's disease retrospectively analysed after 10 years, of whom 30 were treated with corticosteroids. The treatment was most useful in patients with extensive small bowel disease and those with recurrent disease after resection. Immediate improvement was seen in 22 out of the 30 patients, but the longterm results of treatment were only moderately encouraging: seven patients needed continued treatment; eight subsequently required operation; four died; and only three were able to give up the treatment altogether.

In 1958, Crohn and Yarnis found that out of 542 patients with regional ileitis, 385 had needed operation, a high figure indicating the frequent failure of medical treatment. There is little published information on the use of corticosteroids in this disease. Crohn's disease is relatively uncommon and its varied natural history makes a prospective controlled trial into the value of steroid therapy difficult. In an attempt to assess the results of this form of treatment a survey has been made of patients with Crohn's disease and related conditions seen at one hospital during a 10-year period.

\section{SELECTION OF PATIENTS}

A retrospective survey has been made of all patients with Crohn's disease and related conditions admitted to the Central Middlesex Hospital between 1954 and 1964. The characteristic histological appearances of non-caseating giant cell systems were seen in over half the patients. The diagnostic criteria used in selecting the other patients are shown in Table $\mathbf{I}$.

TABLE I

DIAGNOSTIC CRITERIA USED IN THE SELECTION OF PATIENTS

\begin{tabular}{lc} 
Criteria for Diagnosis & $\begin{array}{c}\text { Number of } \\
\text { Patients }\end{array}$ \\
\hline 1 Histology characteristic of Crohn's disease & 54 \\
2 Histology compatible with Crohn's disease & 18 \\
3 Typical clinical picture, radiological, and/or \\
$\begin{array}{l}\text { laparotomy appearances; non-specific histology } \\
\text { Typical clinical picture, radiological and/or }\end{array}$ & 7 \\
laparotomy appearances; no histology & 26
\end{tabular}

Using these criteria a total of 105 patients was available for analysis. Eight patients with a history of less than three weeks in whom a diagnosis of 'acute ileitis' was made at laparotomy have not been included.

A total of 36 patients received corticotrophin or corticosteroids; 30 patients received the drugs alone and seven in combination with anti-tuberculous therapy; one patient received both types of therapy at different times. Anti-tuberculous therapy was given at one period as a pilot trial in view of the histological resemblance between the lesions of Crohn's disease and tuberculosis. The two groups have been analysed separately.

The patients have been classified into four groups based on the distribution of the disease in the bowel as follows:-

(1) 'Extensive small bowel' disease, involving the jejunum and/or proximal ileum; (2) 'ileo-caecal' disease, in which the disease affected mainly the terminal ileum with any colonic disease limited to

\section{TABLE II}

DISTRIBUTION OF DISEASE

\begin{tabular}{lccc} 
Distribution of Disease & All Cases & $\begin{array}{l}\text { Treated with A.C.T.H. } \\
\text { or Corticosteroids }\end{array}$ \\
\cline { 3 - 4 } & & Alone $\quad \begin{array}{l}\text { With Anti- } \\
\text { tuberculous } \\
\text { Drugs }\end{array}$ \\
\hline Extensive small bowel & & & 0 \\
Ileo-caecal & 12 & 5 & 2 \\
Ileo-colic & 56 & 7 & 5 \\
Colon & 27 & 8 & 10 \\
Total & 10 & 10 & 7 \\
& 105 & 30 &
\end{tabular}


TABLE III

DETAILS OF PATIENTS TREATED WITH CORTICOSTEROIDS OR CORTICOTROPHIN ALONE

\begin{tabular}{|c|c|c|c|c|c|c|c|c|c|c|}
\hline Distribution & $\begin{array}{l}\text { Case } \\
\text { No. }\end{array}$ & $\begin{array}{l}\text { Sex } \\
\text { and } \\
\text { Age }\end{array}$ & $\begin{array}{l}\text { Length of } \\
\text { History }\end{array}$ & $\begin{array}{l}\text { Previous } \\
\text { Surgery }\end{array}$ & Drugs & $\begin{array}{l}\text { Initial } \\
\text { Daily } \\
\text { Dose }\end{array}$ & $\begin{array}{l}\text { Duration } \\
\text { of Therapy }\end{array}$ & $\begin{array}{l}\text { Immediate } \\
\text { Outcome }\end{array}$ & $\begin{array}{l}\text { Follow-up from Start of } \\
\text { Treatment }\end{array}$ & $\begin{array}{l}\text { Comment on } \\
\text { Response }\end{array}$ \\
\hline \multirow[t]{5}{*}{$\begin{array}{l}\text { Extensive } \\
\text { small bowel }\end{array}$} & 1 & $\begin{array}{l}\mathbf{M} \\
20\end{array}$ & 14 mth. & - & Pred & $40 \mathrm{mg}$. & 14 mth. & Improved & $\begin{array}{l}\text { Maintained on Pred 10-15 } \\
\text { mg. daily. Well. At work. } \\
\text { Symptoms recur if dose } \\
\text { reduced }\end{array}$ & Good \\
\hline & 2 & $\begin{array}{l}M \\
62\end{array}$ & $3 \mathrm{yr}$. & 2 resections & Pred & $40 \mathrm{mg}$. & 6 wk. & No change & Resection at 2 months & None \\
\hline & 3 & $\begin{array}{l}M \\
32\end{array}$ & $11 \mathrm{yr}$. & 2 resections & Pred & $30 \mathrm{mg}$. & $16 \mathrm{mth}$. & Improved & $\begin{array}{l}\text { Amyloidosis. Died of } \\
\text { uraemia at } 16 \text { months }\end{array}$ & Fair \\
\hline & 4 & $\begin{array}{l}F \\
19\end{array}$ & $18 \mathrm{mth}$. & - & Pred & $30 \mathrm{mg}$. & 14 mth. & Improved & $\begin{array}{l}\text { Maintained in fair health } \\
\text { on Pred. } 10-15 \mathrm{mg} \text {. daily }\end{array}$ & Fair \\
\hline & 5 & $\begin{array}{l}\mathbf{M} \\
\mathbf{3 0}\end{array}$ & $4 \mathrm{yr}$. & - & Pred & $40 \mathrm{mg}$. & $10 \mathrm{mth}$. & Improved & $\begin{array}{l}\text { Symptom-free on Pred. } \\
5-10 \mathrm{mg} \text {. Radiograph } \\
\text { unchanged at } 10 \mathrm{mth} \text {. }\end{array}$ & Good \\
\hline \multirow[t]{7}{*}{ Ileo-caecal } & 6 & $\begin{array}{l}M \\
13\end{array}$ & $3 \frac{1}{2} \mathrm{yr}$. & - & Pred & $20 \mathrm{mg}$. & 12 mth. & Improved & $\begin{array}{l}\text { Symptom-free on Pred. } \\
5-10 \mathrm{mg} \text {. daily. Mild } \\
\text { relapse } 4 \mathrm{mth} \text {. after stopping }\end{array}$ & Good \\
\hline & 7 & $\begin{array}{l}F \\
56\end{array}$ & $16 \mathrm{mth}$. & 1 resection & Pred & $60 \mathrm{mg}$. & 3 wk. & No change & Fairly well 4 yr. later & None \\
\hline & 8 & $\begin{array}{l}\mathrm{F} \\
34\end{array}$ & $9 \mathrm{yr}$. & 3 resections & Pred & $20 \mathrm{mg}$. & $17 \mathrm{mth}$. & No change & Further resection at $3 \mathrm{yr}$. & None \\
\hline & 9 & $\begin{array}{l}\mathbf{F} \\
27\end{array}$ & $3 \mathrm{yr}$. & 1 resection & Pred & $30 \mathrm{mg}$. & 13 mth. & Improved & $\begin{array}{l}\text { Relapse } 6 \mathrm{mth} \text {. after stop- } \\
\text { ping. Symptom-free after } \\
\text { further } 15 \mathrm{mth} \text {. on Pred } \\
10 \mathrm{mg} \text {. daily }\end{array}$ & Good \\
\hline & 10 & $\begin{array}{l}F \\
44\end{array}$ & $9 \mathrm{yr}$. & 2 resections & Pred & $30 \mathrm{mg}$. & 3 wk. & Worse & Further resection at $3 \mathrm{wk}$. & Worse \\
\hline & 11 & $\begin{array}{l}F \\
45\end{array}$ & $3 \frac{1}{2}$ yr. & 3 resections & Pred & $30 \mathrm{mg}$. & $10 \mathrm{mth}$. & Improved & $\begin{array}{l}\text { Symptom-free on Pred. } \\
10 \text { mg. daily }\end{array}$ & Good \\
\hline & 12 & $\begin{array}{l}F \\
39\end{array}$ & $14 \mathrm{yr}$. & 2 resections & A.C.T.H. & 40 units & 3 wk. & Worse & Peritonitis. Died at 3 wk. & Worse \\
\hline \multirow[t]{8}{*}{ Ileo-colic } & 13 & $\begin{array}{l}\mathbf{M} \\
\mathbf{2 3}\end{array}$ & $6 \mathrm{mth}$. & - & Pred & $60 \mathrm{mg}$. & $20 \mathrm{mth}$. & Improved & $\begin{array}{l}\text { Recurrence of pain on Pred. } \\
10 \mathrm{mg} \text {. Minimal pain on } \\
\text { Pred. } 14-20 \mathrm{mg} \text {. }\end{array}$ & Fair \\
\hline & 14 & $\begin{array}{l}\mathbf{F} \\
44\end{array}$ & $4 \mathrm{yr}$. & - & Pred & $60 \mathrm{mg}$. & 5 mth. & Remission & Well 20 mth. later & Good \\
\hline & 15 & $\begin{array}{l}F \\
28\end{array}$ & $6 \mathrm{yr}$. & 4 resections & Pred & $30 \mathrm{mg}$. & $15 \mathrm{mth}$. & Improved & $\begin{array}{l}\text { Faecal fistula at } 15 \mathrm{mth} . \\
\text { Died after resection }\end{array}$ & Fair \\
\hline & 16 & $\begin{array}{l}\mathbf{F} \\
37\end{array}$ & $6 \mathrm{yr}$. & 1 resection & $\begin{array}{l}\text { A.C.T.H. } \\
\text { Pred }\end{array}$ & $\begin{array}{l}80 \text { units } \\
30 \mathrm{mg} \text {. }\end{array}$ & $\begin{array}{l}1 \mathrm{mth} . \\
6 \mathrm{mth} .\end{array}$ & Improved & $\begin{array}{l}\text { Persistent ill-health. } \\
\text { Colectomy at } 7 \mathrm{mth} \text {. }\end{array}$ & Fair \\
\hline & 17 & $\begin{array}{l}\mathbf{M} \\
\mathbf{3 0}\end{array}$ & $8 \mathrm{yr}$. & 1 resection & Pred & $60 \mathrm{mg}$ & 11 wk. & Remission & $\begin{array}{l}\text { Well } 2 \text { yr. later. Radiograph } \\
\text { unchanged }\end{array}$ & Good \\
\hline & 18 & $\begin{array}{l}\mathbf{F} \\
20\end{array}$ & $3 \mathrm{mth}$. & - & $\begin{array}{l}\text { Top. } \\
\text { P21.P }\end{array}$ & $20 \mathrm{mg}$ & 6 wk. & No change & $\begin{array}{l}\text { Persistent ill-health. } \\
\text { Colectomy after } 11 \mathrm{mth} \text {. }\end{array}$ & None \\
\hline & 19 & $\begin{array}{l}F \\
15\end{array}$ & 2 mth. & - & Cort & $200 \mathrm{mg}$ & 2 mth. & Improved & $\begin{array}{l}\text { Maintained in fair health by } \\
\text { repeated courses of Pred. } \\
\text { untilrt. hemicolectomy at } \\
7 \text { yr. }\end{array}$ & Fair \\
\hline & 20 & $\begin{array}{l}F \\
18\end{array}$ & $1 \mathrm{mth}$. & - & Pred & $40 \mathrm{mg}$. & $8 \mathrm{mth}$. & Improved & $\begin{array}{l}\text { Excellent initial response. } \\
\text { Severe relapse } 5 \text { mth. after } \\
\text { stopping Pred. Poor } \\
\text { response to further course }\end{array}$ & Temporary \\
\hline \multirow[t]{9}{*}{ Colon } & 21 & $\begin{array}{l}\mathbf{M} \\
21\end{array}$ & & - & A.C.T.H. & 120 units & 3 days & Worse & $\begin{array}{l}\text { Megacolon with perforation. } \\
\text { Colectomy }\end{array}$ & Worse \\
\hline & 22 & $\begin{array}{l}F \\
62\end{array}$ & 6 mth. & - & Pred & $40 \mathrm{mg}$. & $5 \mathrm{mth}$. & Improved & $\begin{array}{l}\text { Initial good response. Later } \\
\text { deterioration and death at } \\
6 \mathrm{mth} \text {. }\end{array}$ & Temporary \\
\hline & 23 & $\begin{array}{l}M \\
53\end{array}$ & $2 \mathrm{yr}$. & - & $\begin{array}{l}\text { Top } \\
\text { H.H.S. }\end{array}$ & $100 \mathrm{mg}$. & 8 wk. & Improved & $\begin{array}{l}\text { Recurrent ill-health. } \\
\text { Proctocolectomy at } 9 \mathrm{mth} \text {. }\end{array}$ & Fair \\
\hline & 24 & $\begin{array}{l}\mathbf{M} \\
53\end{array}$ & $6 \mathrm{mth}$. & - & $\begin{array}{l}\text { Top } \\
\text { H.H.S. } \\
\text { Pred }\end{array}$ & $\begin{array}{l}100 \mathrm{mg} . \\
40 \mathrm{mg} .\end{array}$ & $\begin{array}{l}3 \text { wk. } \\
10 \text { mth. }\end{array}$ & Improved & $\begin{array}{l}\text { Persistent symptoms. Procto- } \\
\text { colectomy at } 18 \mathrm{mth} \text {. }\end{array}$ & Fair \\
\hline & 25 & $\begin{array}{l}\mathbf{M} \\
\mathbf{3 8}\end{array}$ & $18 \mathrm{yr}$. & - & Pred & 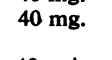 & & No chan & Proctocolectomy at $6 \mathrm{yr}$. & None \\
\hline & 26 & $\begin{array}{l}M \\
61\end{array}$ & $3 \mathrm{yr}$. & 2 resections & A.C.T.H. & 40 units & 3 wk. & Improved & $\begin{array}{l}\text { Relapse at } 3 \mathrm{mth} \text {. Died of } \\
\text { myocardial infarct }\end{array}$ & Temporary \\
\hline & 27 & $\begin{array}{l}F \\
58\end{array}$ & $10 \mathrm{mth}$. & - & $\begin{array}{l}\text { Top } \\
\text { H.H.S. } \\
\text { Pred }\end{array}$ & $\begin{array}{l}100 \mathrm{mg} . \\
20 \mathrm{mg} .\end{array}$ & $\begin{array}{l}2 \text { wk. } \\
5 \text { wk. }\end{array}$ & nproved & $\begin{array}{l}\text { Improvement not maintained } \\
\text { Resection at } 9 \mathrm{mth} \text {. }\end{array}$ & Fair \\
\hline & $\begin{array}{l}28 \\
29\end{array}$ & $\begin{array}{l}F \\
47 \\
F \\
29\end{array}$ & $\begin{array}{l}12 \mathrm{yr} . \\
2 \mathrm{yr} .\end{array}$ & - & A.C.T.H. & 80 units & 8 wk. & $\begin{array}{l}\text { Remission } \\
\text { Improved }\end{array}$ & \multirow{2}{*}{$\begin{array}{l}\text { Severe relapse } 2 \text { yr. later. } \\
\text { Resection at } 3 \frac{1}{2} \text { yr. } \\
\text { Severe relapse at } 4 \text { mth. } \\
\text { Emergency colectomy } \\
\text { Symptomatic benefit but } \\
\text { continued ill-health. Procto- } \\
\text { colectomy } 3 \text { yr. }\end{array}$} & $\begin{array}{l}\text { Good } \\
\text { Temporary }\end{array}$ \\
\hline & 30 & $\begin{array}{l}\text { M } \\
24\end{array}$ & $3 \mathrm{mth}$. & - & $\begin{array}{l}\text { A.C.T.H. } \\
\text { Pred }\end{array}$ & $\begin{array}{l}80 \text { units } \\
45 \text { mg. }\end{array}$ & $\begin{array}{l}4 \text { wk. } \\
20 \mathrm{mth} .\end{array}$ & $\begin{array}{l}\text { Improved } \\
\text { Improved }\end{array}$ & & Fair \\
\hline
\end{tabular}

Pred = prednisone; A.C.T.H. $=$ corticotrophin Cort $=$ cortisone; Top. P21-P = topical prednisolone 21-phosphate; Top H.H.S. $=$ topical hydrocortisone hemisuccinate 
the caecum; (3) 'ileo-colic' disease where the disease involved the ileum and the colon distal to the caecum; (4) 'colonic' disease where the large bowel only was involved.

The distribution of disease in the whole series and in the treated group is shown in Table II.

Analysis has been restricted to treatment given at the Central Middlesex Hospital. The doses given and the duration of therapy varied from case to case. All patients except two, treated topically, received at least 40 units of corticotrophin or the equivalent of $100 \mathrm{mg}$. of cortisone daily. Apart from case 21 (below) treatment was given for a minimum of three weeks. Anti-tuberculous therapy consisted of at least two of the drugs, streptomycin, P.A.S., or I.N.A.H., and the duration of treatment varied from two weeks to seven months.

Follow-up of patients treated with corticosteroids or corticotrophin has been continued to March 1965 , or until surgical treatment was required.

The results of therapy have been classified into one of four groups: remission, improved, no change, or worse.

The disease has been regarded as in remission when the patient has remained well for at least six months after discontinuing treatment.

Assessment of improvement has been difficult since non-specific subjective improvement is common with steroid therapy. A subjective response was shown by increased well being, improved appetite, and disappearance or reduction of abdominal pain and diarrhoea. Objective evidence included a fall in pyrexia, a decrease in diarrhoea, an increase in weight and haemoglobin, and a decrease in erythrocyte sedimentation rate. In every case classified as improved there has been subjective benefit and in the majority one or more objective criteria of response were also present.

\section{RESULTS OF TREATMENT WITH CORTICOSTEROIDS OR CORTICOTROPHIN WITHOUT ANTI-TUBERCULOUS THERAPY}

Details of all the patients treated are set out in Table III.
IMMEDIATE RESULTS The immediate results of treatment are shown in Table IV.

Assessment of the initial response to treatment showed that three patients went into remission.

Case 14 A 44-year-old woman with a rectal stricture and the radiological appearances of Crohn's disease of the terminal ileum and caecum had a four-year history of intermittent abdominal pain and diarrhoea. After an exacerbation of symptoms, prednisone $60 \mathrm{mg}$. daily was started. She lost all her symptoms, gained weight, and returned to normal health. The E.S.R. fell from $24 \mathrm{~mm}$. to $6 \mathrm{~mm}$. in one hour. Maintenance prednisone therapy was discontinued after five months. The stricture is no longer palpable and she remains well 15 months after stopping treatment.

Case 28 A 47-year-old woman, with a 12-year history of diarrhoea, rectal bleeding, and anal fissures, was thought to be suffering from ulcerative colitis, involving the descending colon. A severe relapse was treated with prednisone $45 \mathrm{mg}$. daily. This resulted in subjective and objective improvement and after maintenance treatment with prednisone had been discontinued four months later, she remained well for two years. A severe relapse then occurred and a left hemi-colectomy was performed 18 months later. The colon showed the characteristic histology of Crohn's disease.

Case 17 A 30-year-old man had a right hemi-colectomy eight years previously for ileo-caecal Crohn's disease. Following a recurrence of abdominal pain and diarrhoea, investigation showed disease involving the terminal ileum, transverse and descending colon. On an initial dose of prednisone of $60 \mathrm{mg}$. daily he improved symptomatically and objectively and after corticosteroids were discontinued 11 weeks later he remained well for 22 months. A slight symptomatic relapse at this time settled without corticosteroid therapy and he remains well two years after stopping treatment. Repeat barium enema at two years shows no change.

Nineteen of the 30 patients had immediate benefit but did not go into remission. Their subsequent course will be dealt with below. Of the eight patients who did not respond, five were unchanged, one died (see below), and the following two patients deteriorated.

Case 10 A 44-year-old woman with a nine-year history of Crohn's disease had had two previous resections. When the disease recurred at the anastomosis with

TABLE IV

IMMEDIATE RESULTS OF TREATMENT WITH CORTICOSTEROIDS OR CORTICOTROPHIN WITHOUT ANTI-TUBERCULOUS THERAPY

\begin{tabular}{l} 
Distribution of Disease \\
\hline Extensive small bowel \\
Ileo-caecal \\
Ileo-colic \\
Colon \\
Total
\end{tabular}

$\begin{array}{lll}\text { Number } & \text { Previous } & \text { No } \\ \text { Treated } & \text { Surgery } & \text { Surgery }\end{array}$

$\frac{\text { Results }}{\text { Remission }}$

Imp


incomplete obstruction and an internal fistula, prednisone $30 \mathrm{mg}$. daily was given. She failed to respond and developed increasing pyrexia and persistent abdominal distension. After three weeks a further resection was done and abscesses were drained.

Case 21 A 21-year-old man developed a toxic megacolon having had iritis, diarrhoea, and fever for two weeks. He was given A.C.T.H., 120 units, daily but three days later the colon perforated and an emergency colectomy was performed. Histological examination of the colon suggested Crohn's disease though clinically the disease appeared to be typical ulcerative colitis. He has remained well for two and a half years since the operation.

SUBSEQUENT COURSE IN PATIENTS SHOWING INITIAL IMPROVEMENT When the subsequent course of those patients who responded initially is summarized (Table V) it will be seen that the early favourable picture alters. Only one patient (case 14) remains in good health after stopping treatment, and two patients (cases 6 and 71) have had a mild relapse which has required no treatment. Four of the 22 patients who benefited initially have died (see below), eight have had a further relapse, and the remaining seven patients are still on therapy. Two illustrative cases from the group continuing therapy are as follows.

Case 1 A 20-year-old man, previously investigated for weight loss and a megaloblastic anaemia, was admitted with a few weeks' history of increasing abdominal pain. He was pyrexial, had subacute obstruction, and an E.S.R. of $46 \mathrm{~mm}$. in one hour. Radiographs showed mucosal abnormalities and strictures in the jejunum and ileum. Prednisone, $40 \mathrm{mg}$. daily, was started and within 24 hours the pain ceased and later his temperature fell to normal as did his E.S.R. Apart from an exacerbation of pain on one occasion when corticosteroids were temporarily reduced, he has remained well and at work on maintenance therapy of 10 to $15 \mathrm{mg}$. of prednisone daily for 14 months.

Case 11 A woman aged 45 had a right hemi-colectomy three and a half years previously for ileo-caecal Crohn's disease. Fifteen months later, after developing a fistula and abscess, she required a further resection. A year later a third resection was performed after she had developed a discharging sinus of the abdominal wall. When diarrhoea and colic recurred a few months later a mass became palpable in the right iliac fossa and further radiographs showed Crohn's disease of the remaining ileum. Symptomatic therapy did not control the symptoms, and, as it was felt that further surgery should be avoided if possible, prednisone $40 \mathrm{mg}$. daily was started. There was considerable subjective improvement with a decrease in pain and diarrhoea, and objectively the palpable mass decreased in size. She remains well after 10 months while taking prednisone $10 \mathrm{mg}$. daily, but symptoms recur if the dose is reduced.

Resections were performed on eight of the patients who had shown an initial improvement. Table V shows that six of these had Crohn's disease of the colon and the other two had ileo-colic disease. The time between the start of therapy and resection varied from three months to seven and a half years.

\section{RESULTS OF COMBINED CORTICOTROPHIN OR CORTICOSTEROID AND ANTI-TUBERCULOUS TREATMENT}

Seven of the 105 patients received combined therapy, and details of these patients are set out in Table V. The immediate results of the treatment were that one went into remission, three were improved, two were unchanged, and one became worse and died after resection (case 33 below). The patient whose disease went into remission is well seven years later and has required no further treatment. Of the three patients who were improved, two have had a resection. The third patient is of particular interest.

Case 34 A man of 18 who had had ileo-colic Crohn's disease by-passed with an ileo-transverse colostomy, developed pneumaturia. He was found to have a mass in the recto-vesical pouch and a vesico-colic fistula. His Mantoux reaction was negative and no acid-fast bacilli were found in his urine. Prednisone, streptomycin, and I.N.A.H. were given, the prednisone being discontinued after seven weeks and the anti-tuberculous drugs being maintained for six months. He greatly improved on this therapy and apart from an episode of pneumaturia a year later he has now remained well for six years.

\section{DEATHS DURING AND AFTER TREATMENT}

There have been six deaths among the patients treated with corticosteroids or corticotrophin. Details of these patients are as follows:-

\section{TABLE V}

SUBSEQUENT COURSE IN PATIENTS SHOWING INITIAL IMPROVEMENT WHEN TREATED WITH CORTICOSTEROIDS OR CORTICOTROPHIN WITHOUT ANTI-TUBERCULOUS THERAPY

\begin{tabular}{|c|c|c|c|c|}
\hline Distribution of Disease & $\begin{array}{l}\text { Number with } \\
\text { Initial Response }\end{array}$ & $\begin{array}{l}\text { No Further } \\
\text { Treatment }\end{array}$ & $\begin{array}{l}\text { Continuing } \\
\text { Treatment }\end{array}$ & Resection \\
\hline Extensive small bowel & 4 & 0 & 3 & 0 \\
\hline Ileo-colic & 7 & 2 & 2 & 2 \\
\hline Colon & 8 & $\mathbf{0}$ & $\mathbf{0}$ & 6 \\
\hline Total & 22 & 3 & 7 & 8 \\
\hline
\end{tabular}


TABLE VI

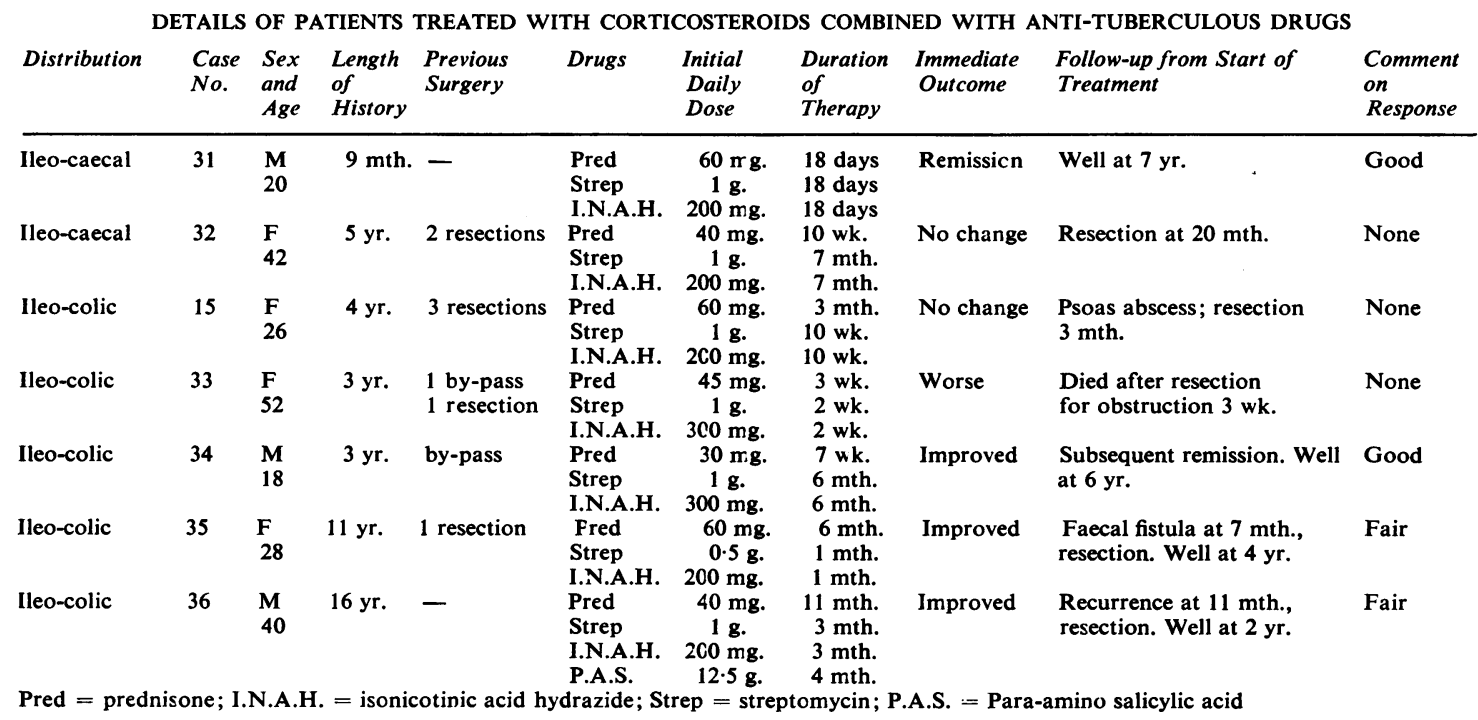

Case 3 A 32-year-old man with extensive small bowel Crohn's disease associated with amyloidosis and the nephrotic syndrome received prednisone for 16 months. His bowel symptoms improved but he died of renal failure.

Case 12 A 39-year-old woman developed a faecal fistula after a resection for ileo-caecal Crohn's disease. A second resection was performed but the fistula recurred. There was no evidence of recurrent Crohn's disease in the resected specimen. Further surgical treatment seemed unlikely to help, and, as her condition was deteriorating rapidly, she was given A.C.T.H. 40 units daily. She continued to deteriorate and died three weeks later. Post-mortem examination showed a low-grade peritonitis and two liver abscesses.

Case 15 A 28-year-old woman with extensive Crohn's disease had had four previous resections. Her last resection two years previously was performed when she developed a psoas abscess two months after starting therapy with prednisone, streptomycin, and I.N.A.H. Prednisone was given again two years later for a recurrence of Crohn's disease. Following 15 months' therapy a faecal fistula developed and a fifth resection was performed. This left very little bowel and she died three months later of malnutrition.

Case 22 A 62-year-old woman had a six-month history of diarrhoea and anal ulceration which, on biopsy, had the histological appearances of Crohn's disease. She improved greatly on prednisone $40 \mathrm{mg}$. daily and the ulcer healed. During continued prednisone therapy, her condition deteriorated with persistent fever and diarrhoea and she died six months later. Postmortem examination showed segmental ulceration in the colon.

Case 26 A 61-year-old man with two previous resections for Crohn's disease of the sigmoid colon responded to a three-week course of A.C.T.H. after a further relapse.
He relapsed again three months later but died of a myocardial infarct before further treatment was given.

Case 33 A woman of 52, with a six-year history, had the first operation for Crohn's disease three years before and it was complicated by faecal fistula. Peri-anal ulceration and sepsis led to incontinence. The disease recurred at the anastomosis and right hemi-colectomy was performed. When treated with prednisone, streptomycin, and I.N.A.H. 18 months later she was ill, malnourished, and suffering from episodes of obstruction from an ileal recurrence. She died 11 days after a further resection of ileum and construction of an ileostomy.

It will be seen that one patient (case 26) died of an unrelated disease and one patient (case 3 ) died of pre-existing amyloidosis. In case 15 corticosteroids failed to prevent extension of the disease and she died from malabsorption. Corticotrophin was given as post-operative supportive treatment to case $\mathbf{1 2}$ and may have contributed to her death. In retrospect, medical treatment in case 22 was persisted with for too long.

\section{COMPLICATIONS DURING TREATMENT}

Apart from mooning, seen in some patients, the complications occurring during treatment are listed in Table VII.

\section{DISCUSSION}

In this group of 105 patients over one third received corticotrophin or corticosteroid therapy during their illness. Definitive surgery was frequently 
TABLE VII

COMPLICATIONS DURING TREATMENT

\begin{tabular}{rlcl}
$\begin{array}{l}\text { Case } \\
\text { No. }\end{array}$ & Distribution of Disease & $\begin{array}{l}\text { Duration of } \\
\text { Therapy }(\text { mth. })\end{array}$ & Complication \\
\hline 3 & Extensive small bowel & 8 & Pancreatitis \\
15 & Ileo-colic & 3 & Psoas abscess \\
15 & Ileo-colic & 15 & Faecal fistula \\
35 & Ileo-colic & 6 & Faecal fistula \\
21 & Colon & 3 days & Perforation
\end{tabular}

required and only 27 of the 105 patients have been treated so far by medical means alone. This is in accord with most published series. Published reports on the use of corticosteroids or corticotrophin in the treatment of Crohn's disease are few and Edwards (1964) could find little convincing evidence of their value in the literature. Crohn and Yarnis (1958) suggest that the results with these drugs are not as good in regional ileitis as in ulcerative colitis. However, they regard small doses of corticosteroids given for months, or even years, as the best treatment available for extensive small bowel disease. In their experience, these drugs improve appetite and well-being and reduce fever in regional ileitis, but have little effect on diarrhoea. In ileo-colitis they recommend corticotrophin as of value in the acute stages of the illness followed by maintenance with oral corticosteroids.

From Table $I$ it will be seen that in this series corticosteroids and corticotrophin were used in all types of disease and both before and after resection. As might be expected, the disease most commonly involved the terminal ileum and caecum with a smaller incidence of extensive small bowel and purely colonic disease. About half of the group with extensive small bowel involvement received corticosteroids because resection was impracticable. All the patients with purely colonic disease received corticosteroids or corticotrophin because a diagnosis of ulcerative colitis, in which the benefits of steroids are known, was made. The distinction between ulcerative colitis and Crohn's disease of the colon has recently been reviewed by Lockhart-Mummery and Morson (1964).

When the initial effect of therapy is studied the results look promising. Of the $\mathbf{3 0}$ patients treated without additional anti-tuberculous therapy, 22 improved and only three deteriorated during treatment. This improvement was seen in patients with all types of disease and there was no evidence that any group responded better or worse than the others. The only serious early complication during therapy occurred in a patient who clinically behaved as a case of ulcerative colitis with a toxic megacolon.

Despite this early encouraging response to corticosteroids the later outcome for these patients was less favourable. Of the 22 patients who responded initially, four have died and eight have had a further resection. Three patients have required no further treatment. Seven patients, including several in whom surgery is contraindicated, are maintained in fair health on long-continued corticosteroids. In these patients symptoms tend to return when the dosage of steroids is lowered, suggesting that the disease is still active.

The results in the group treated with antituberculous drugs in addition to corticosteroids or corticotrophin were little different from those already discussed. The numbers are too small to draw any conclusion as to whether the addition of these drugs was beneficial. Recent publications (Lee and Roy, 1964; Howell and Knapton, 1964) have re-emphasized the difficulty of distinguishing between ileo-caecal Crohn's disease and tuberculosis. Where doubt exists treatment with corticosteroids alone may be hazardous and the addition of anti-tuberculous treatment is advisable.

The possible dangers of corticosteroid therapy are well known. In this series many of the complications and deaths during treatment can be ascribed to the disease process. On these results the risks of corticosteroid therapy in selected cases does not appear excessive.

The experience reported here suggests that corticosteroid therapy may be beneficial in certain cases of Crohn's disease but that the treatment often has to be continued for long periods. The clearest indications for this therapy, which carries its own hazards, are (1) patients with extensive small bowel disease and (2) patients who have recurrent disease after resection. Although the results of conservative therapy in localized disease are unsatisfactory, the recurrence rate after surgical treatment is high (Davis, 1961). In this series 28 patients required two or more resections. The results of corticosteroid therapy in some of the cases with localized disease reported here are perhaps sufficiently encouraging to justify a formal prospective trial of this treatment in Crohn's disease.

\section{SUMMARY}

A retrospective study has been made of 105 patients with Crohn's disease and related conditions admitted to the Central Middlesex Hospital in the period 1954-64.

Initial improvement occurred in 22 of 30 patients treated with corticosteroids or corticotrophin without anti-tuberculous therapy. Only three of the 22 patients have required no further therapy; seven are maintained in fair or good health by longcontinued corticosteroid therapy; eight have been treated by resection, and four have died. 
Seven patients were treated with a combination of corticosteroids or corticotrophin and antituberculous drugs. Numbers are too small to show whether the addition of anti-tuberculous therapy was beneficial.

Complications and deaths during corticosteroid therapy have been reviewed.

The clearest indications for corticosteroid therapy appear to be extensive disease of the small bowel or recurrence of the disease after resection.

We thank Dr. F. Avery Jones and Dr. T. D. Kellock for their encouragement, and Mr. T. G. I. James, Mr.
F. H. Henley, and Mr. J. W. P. Gummer, who have also allowed us to study their patients.

\section{REFERENCES}

Crohn, B. B., and Yarnis, H. (1958). Regional Ileitis, 2nd ed., Grune and Stratton, New York.

Davis, J. M. (1961). The prognosis of Crohn's disease of the small intestine. Postgrad. med. J., 37, 783-791.

Edwards, H. (1964). Crohn's disease. J. roy. Coll. Surg. Edinb., 9, $115-127$.

Howell, J. S., and Knapton, P. J. (1964). Ileo-caecal tuberculosis. Gut, 5, 524-529.

Lee, F. D., and Roy, A. D. (1964). Ileo-caecal granulomata. Ibid., 5, 517-523.

Lockhart-Mummery, H. E., and Morson, B. C. (1964). Crohn's disease of the large intestine. lbid., 5, 493-509. 